\title{
Bone Densitometry and Calcium Serum Levels in Chickens Treated With Filtered or Unfiltered Water
}

\section{mAuthor(s)}

Amoroso $L^{*}$

Baraldi ASM

Barreiro FR'

Pacheco MR'

Alva JCR'

Soares NM"

Pacheco LG'II

Melaré MCIII

IDepartment of Animal Morphology and Physiology, Faculdade de Ciências Agrárias e Veterinárias de Jaboticabal - UNESP

" Research and Development Unit of Biological Institute (APTA), Bastos, SP, Brazil

III Undergraduate students of Animal Science, Faculdade de Ciências Agrárias e Veterinárias de Jaboticabal - UNESP

\section{-Mail Adress}

Corresponding author e-mail address

Departamento de Morfologia e Fisiologia Animal, Faculdade de Ciências Agrárias e Veterinárias (FCAV), Universidade Estadual Paulista (UNESP), Rodovia de Acesso Paulo Donato Castellane, s/n, km 5. Jaboticabal, SP 14884-900, Brazil.

*Author for mailing: lizandra@fcav.unesp.br

\section{-Keywords}

Bone mineral density, broilers, serum calcium levels, tibia, water quality.

\section{ABSTRACT}

The aim of this study was to evaluate whether the drinking water of the School of Agricultural and Veterinary Sciences, UNESP, Jaboticabal, Brazil, affected bone mineral density and serum calcium levels of 14-, 21-, and 45-day-old broilers. Bone mineral density (BMD) of the tibiae was assessed using optical densitometry radiographic technique and serum calcium levels. Tibial BMD increased as broilers aged, and achieved its peak at 45 days of age. It was higher in the distal epiphysis of the birds that ingested filtered water $(p<0.05)$ compared with those supplied with unfiltered water. Therefore, it is concluded that filtered water promoted better bone quality in relative to those ingested unfiltered water.

\section{INTRODUCTION}

Because bone tissue is being constantly reshaped and replaced, techniques that are able to detect disorders in skeleton mineralization early in poultry life may contribute to their prevention (Charuta \& Cooper, 2012).

Bone mineral density (BMD) is a biophysical parameter of experimental and clinical importance that aids bone structure assessment (Louzada et al., 1997). Sequential analyses of variations in bone density are based on the comparison of bone $x$-ray images with an aluminum scale, because the density of this metal is similar to that of bone hydroxyapatite (Saraiva \& Lazaretti Castro, 2002).

The high metabolic activity of broilers makes drinking water more important for their development relative to other species (Bruno \& Macari, 2002). Accelerated growth favors metabolic disorders that hinder mineral deposition in the skeleton, resulting in significant bone disease incidence (Angel, 2007).

Moreover, as the skeleton of broilers is still developing during the growo ut, their heavy body weight may cause musculoskeletal disorders (Mendonça Jr., 2009). In this sense, studies on locomotion problems may contribute to improve broiler welfare and to prevent economic losses in the poultry industry (Almeida Paz, 2008). The fast growth rates of modern broilers may cause bones to be less resistant and less rigid (Driver et al., 2005), and therefore their locomotion apparatus is relatively immature, with little compact bone tissue at slaughter age (Mendonça Jr., 2009). Therefore, the early evaluation of BMD provides data on skeleton quality and may aid the diagnosis of common disorders, such as tibial dyschondroplasia in broilers (Almeida Paz et al., 2004), degenerative joint lesions in the femoral region (Almeida Paz et al. 2008, Almeida Paz et al., 2009), and hypocalcemia and osteoporosis in laying hens (Julian, 2005).

Bone mineral density is regulated by remodeling in the adult skeleton and directly influences bone strength. Therefore, bone health depends 
on bone mass, geometry and composition, material properties, and microstructure (Clarke, 2008).

Approximately, 98 to $99 \%$ of total body calcium and 80 to $85 \%$ of phosphorus are located in the bones. When calcium blood concentration decreases, calcium is mobilized from the bones to maintain its physiological blood level (Scott et al., 1982).

As it is a dynamic mineral reserve, the skeletal system provides information on calcium homeostasis (Chang et al., 2008). Because dietary calcium affects in bone development and there are no data in literature on the effects of drinking water calcium level on chicken bone density, the influence of water source on bone density and serum calcium levels of 14- to 45-day-old was investigated.

\section{MATERIAL AND METHODS}

The experiment was carried out in an experimental broiler house at the Poultry Sector of of the Animal Science Department of the School of Agricultural and Veterinary Sciences of Unesp, Jaboticabal, SP, Brazil. The experimental procedures were reviewed and approved by Ethics and Animal Welfare Committee, of that university under protocol n. 000422-08.

In the experiment, 1120 one-day-old male Cobb chicks were distributed according to a completely randomized experimental design in two treatments with 16 replicates each, totaling 32 pens with 35 birds each. Treatments consisted of the supply of filtered water (Hidrofiltros $®$ filter) and unfiltered water from UNESP, Jaboticabal campus, in nipple drinkers.

A feeding regime of three phases was adopted (17, 8-21, and 22-45 days). The diets were based on corn and soybean meal and formulated according to nutritional recommendations and ingredient composition proposed by Rostagno et al. (2005), as shown in Table 1.

Birds were submitted to the management practices recommended by the genetic company's manual, and an intermittent lighting program was applied. Until 20 days of age, chicks were brooded using one heating source per pen that was controlled according to birds' behavior. After that, environmental temperature was controlled by side curtain and fan management, when needed.

Table 1 - Ingredients and calculated composition of the experimental diets

\begin{tabular}{|c|c|c|c|}
\hline Ingredients & Rearing pha & & \\
\hline$(\%)$ & 1 to 7 days & 8 to 21 days & 22 to 45 days \\
\hline Corn & 56.69 & 62.43 & 66.13 \\
\hline Soybean meal & 36.80 & 29.99 & 25.99 \\
\hline Soybean oil & 2.93 & 4.43 & 4.90 \\
\hline Dicalcium phosphate & 1.83 & 1.57 & 1.42 \\
\hline Limestone & 0.86 & 0.79 & 0.74 \\
\hline Salt & 0.42 & 0.41 & 0.38 \\
\hline DL- methionine (99\%) & 0.22 & 0.16 & 0.16 \\
\hline L-Lysine & 0.15 & 0.12 & 0.18 \\
\hline Vitamin and mineral supplement* & 0.10 & 0.10 & 0.10 \\
\hline Total & 100 & 100 & 100 \\
\hline \multicolumn{4}{|l|}{ Calculated composition } \\
\hline Metabolizable energy (kcal/kg) & 3.00 & 3.17 & 3.25 \\
\hline Protein (\%) & 21.6 & 19.0 & 17.5 \\
\hline Calcium (\%) & 0.92 & 0.81 & 0.74 \\
\hline Available phosphorus (\%) & 0.46 & 0.40 & 0.37 \\
\hline Total phosphorus (\%) & 0.71 & 0.63 & 0.59 \\
\hline Digestible lysine (\%) & 1.28 & 1.07 & 1.01 \\
\hline Total lysine (\%) & 1.31 & 1.11 & 1.05 \\
\hline Digestible methionine + cystine (\%) & 0.91 & 0.77 & 0.73 \\
\hline Total methionine + cystine (\%) & 0.93 & 0.79 & 0.75 \\
\hline Digestible methionine (\%) & 0.55 & 0.45 & 0.42 \\
\hline Total methionine (\%) & 0.56 & 0.46 & 0.44 \\
\hline
\end{tabular}


Birds were vaccinated against Newcastle disease and infectious bursal disease by eye drop on day 8 , and received a booster vaccination on day 14 .

Filtered and unfiltered water were sampled before the experiment and stored in 1-L plastic flasks. Samples were collected directly from the tap and the filter installed in the pens to evaluate the influence of water treatment system on chemical water quality. Analytical determinations were performed by the Department of Technology from School of Agriculture and Veterinary Sciences, Unesp.

On days 14, 21 and 45, twenty birds per treatment were anesthetized with ketamine and Zoletil $®$, sacrificed, and their right tibiae were collected, and subsequently submitted to bone densitometry.

An aluminum phantom was used as densitometric reference for the radiographic samples. This phantom or penetrometer (metal alloy 6063, in accordance with the Brazilian Association of Technical Norms) has of 12 steps, ranging between 0.5 and $5.0 \mathrm{~mm}$ until the tenth step; the eleventh was $6.0 \mathrm{~mm}$ thick, and the twelfth was $8.0 \mathrm{~mm}$ thick; each step area was $5 \times 25 \mathrm{~mm}^{2}$, and was radiographed simultaneously with the bones.

The penetrometer was placed parallel to the tibia, so that the highest steps were in highest region of the chassis. Radiographs were taken by an X-ray apparatus (Siemens Tridoro 812 E) in the Radiography Sector of the Veterinary Hospital Laudo Natel of the School of Agriculture and Veterinary Sciences. P-MATG/RA Kodak films were used, and chassis measuring $18 \times 24 \mathrm{~cm}$, $24 \times 30 \mathrm{~cm}$ and $30 \times 40 \mathrm{~cm}$ were used for tibiae collected on days 14, 21, and 45, respectively. Metal chassis were fitted with intensifying screens (Regular Lanex). The films, previously identified by printing devices, were revealed and fixed in an automatic processor (Kodak X-OMAT 200). Radiographs were scanned for reading in BMD software Image Pro Plus $®$ (version 4.1, Media Cybernetics, Silver Spring, MD) at the Morphology and Physiology Department. Densitometry values were expressed in millimeters of aluminum ( $\mathrm{Al} \mathrm{mm}$ ), according to Louzada (1997).

Blood samples, corresponding to one milliliter of blood, were collected from the axillar vein of 32 randomly selected birds at each rearing phase (14, 21 and 45 days, respectively), for serum calcium determination. Blood was placed in 1.5-mL Eppendorf tubes and centrifuged at 3000 rpm for 15 minutes to obtain the serum. Calcium serum levels were determined using a commercial kit (Labtest ${ }^{\circledR}$ ).

The results were submitted to analysis of variance, evaluating tibial regions (proximal epiphysis, diaphysis, and distal epiphysis) and age factor (14, 21 and 45 days). Means were compared by the test of Tukey at $5 \%$ significance level (SAS, 2004).

\section{RESULTS AND DISCUSSION}

Bone mineral density (BMD; $p<0.05)$ increased as birds aged (Table 2). Barreiro et al. (2011) also found increasing BMD values during the early stages of broilers development, in agreement with Yalçin et al. (2001), who stated that the first 16 days of life are crucial for the development of the tibia in broilers, stressing the significant effect of age on bone anatomy.

Independently of treatment used, in thus experiment, mean tibial BMD was different among the different sections analyzed: it was higher in proximal and distal epiphysis compared with the diaphysis. Oliveira et al. (2009) also observed variations in BMD among sections (proximal epiphysis, diaphysis and distal epiphysis) of the tibia of 21-d-old broilers.

Bone growth and mineralization are intensive physiological processes during the first two weeks of the broiler's life (Julian, 2005). In the present experiment, BMD was higher in diaphysis and proximal epiphysis $(p<0.05)$ of birds which had access to filtered relative unfiltered water when broilers were 14 days old, but there was no effect ( $p>0.05$ ) of treatments on the BMD of the distal epiphysis (Table 2). On day 21, the BMD of the proximal epiphysis of tibia of broilers that consumed filtered water was higher than those supplied with unfiltered water (Figure 1), but the BMD of the diaphysis and distal epiphysis of birds receiving unfiltered water was higher relative to filtered water $(p<0.05$; Figure 2).

On day 45 , the BMD values of the proximal epiphysis and diaphysis were not different between treatments ( $p>0.05)$, probably because there is a pattern of muscle, ligament, and tendon development that depends on bone status and that stabilizes as birds grow. Although Barreiro et al. (2009) observed that the proximal epiphysis of the tibiae of 43-d-old broilers presented higher bone mineral density than those obtained in the present study. Araújo et al. (2006) reported that different dietary calcium levels did not influence tibial densitometry of 49-d-old layers. According to Almeida Paz and Bruno (2006), the BMD profile of developing long bones is not different among chicken strains.

On day 45, BMD of the distal epiphysis of the broilers that ingested filtered water was higher compared with those supplied unfiltered water $(p<0.05)$, but the treatments did not influence $(p>0.05)$ proximal 
Amoroso L, Baraldi ASM, Barreiro FR Pacheco MR, Alva JCR, Soares NM,

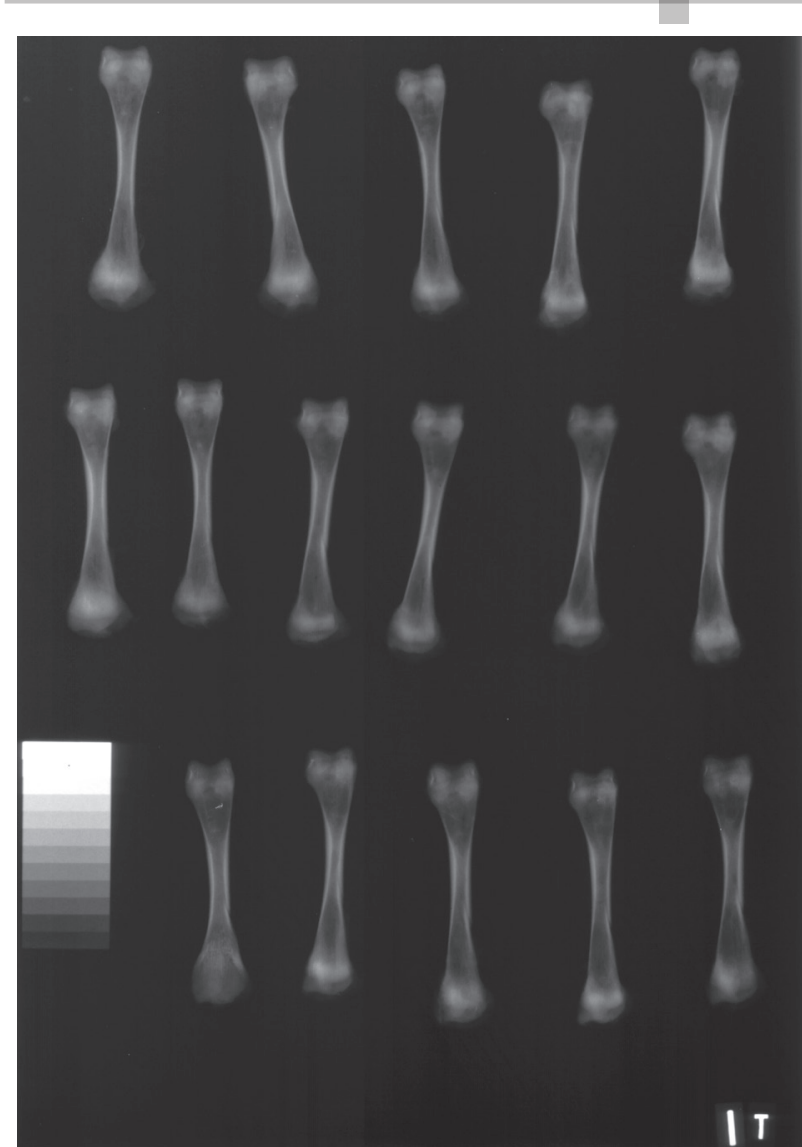

Figure 1 - Radiographic image of the tibia of 21-d-old broilers supplied with filtered water.

epiphysis and diaphysis BMD (Table 2). Because the distal epiphysis of the tibia is subject to higher pressure and impact during movement, it is suggested that the broilers that ingested filtered water may present greater biomechanical stability.

Table 2 - Mean ( \pm standard deviation) bone mineral density ( $\mathrm{mm} \mathrm{Al}$ ) of the proximal epiphysis, diaphysis and distal epiphysis of the tibiae of broilers supplied with filtered or unfiltered water between 14 and 45 days of age.

\begin{tabular}{|c|c|c|}
\hline Age & \multicolumn{2}{|c|}{ Proximal epiphysis } \\
\hline (days) & Filtered water & Unfiltered water \\
\hline 14 & $1.72 \pm 0.11 \mathrm{a}$ & $1.44 \pm 0.03 b$ \\
\hline 21 & $1.73 \pm 0.09 a$ & $1.44 \pm 0.03 b$ \\
\hline \multirow[t]{2}{*}{45} & $3.09 \pm 0.18 a$ & $3.04 \pm 0.09 a$ \\
\hline & \multicolumn{2}{|l|}{ Diaphysis } \\
\hline 14 & $1.72 \pm 0.05 a$ & $1.43 \pm 0.04 b$ \\
\hline 21 & $1.79 \pm 0.08 b$ & $2.20 \pm 0.11 \mathrm{a}$ \\
\hline \multirow[t]{2}{*}{45} & $2.29 \pm 0.09 a$ & $2.11 \pm 0.09 a$ \\
\hline & \multicolumn{2}{|l|}{ Diaphysis } \\
\hline 14 & $1.35 \pm 0.08 a$ & $1.28 \pm 0.32 \mathrm{a}$ \\
\hline 21 & $1.40 \pm 0.06 b$ & $1.82 \pm 0.16 a$ \\
\hline 45 & $2.73 \pm 0.57 b$ & $2.25 \pm 0.57 \mathrm{a}$ \\
\hline $\mathrm{CV} \%$ & & \\
\hline
\end{tabular}

Means followed by the same lowercase letters in the same row are not different ( $p>0.05)$.

$\mathrm{CV}=$ coefficient of variation

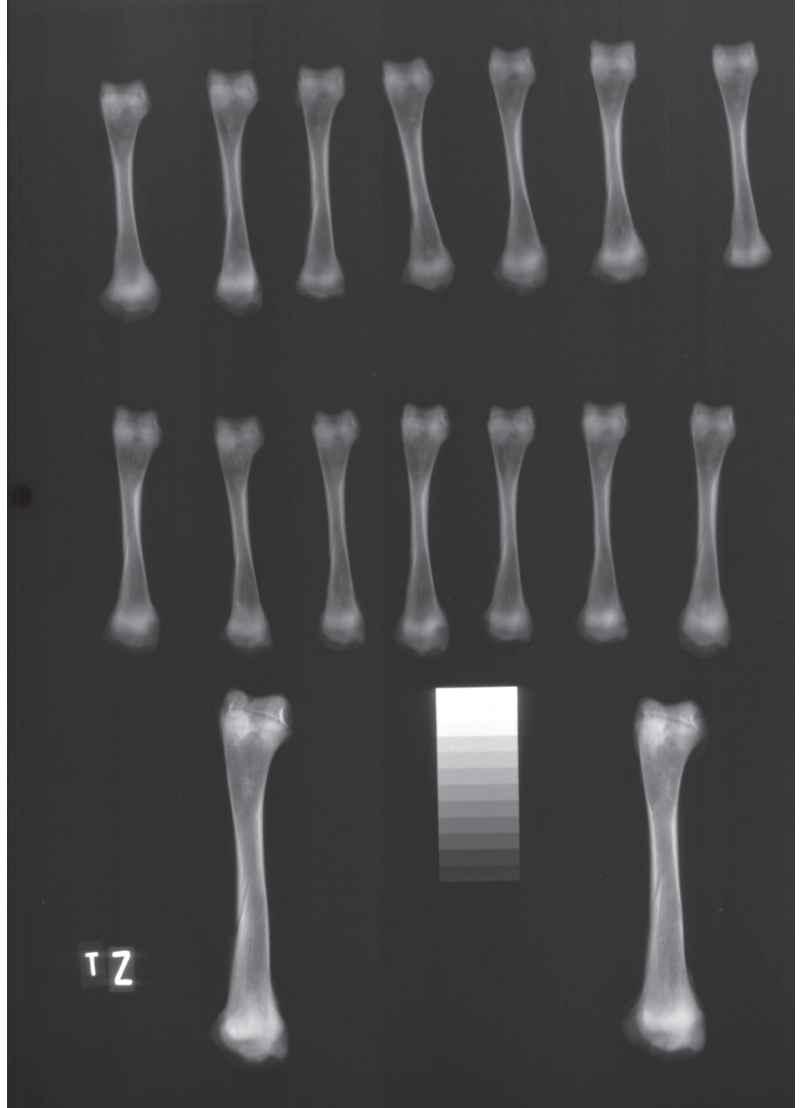

Figure 2 - Radiographic image of the tibia of 21-d-old (A) and 45-d-old broilers supplied with unfiltered water.

The present results also indicates that the broilers fed filtered water may have stronger bones, providing adequate support to muscles, tendons, and ligaments. This was observed in experiment of Barreiro et al. (2011), who mentioned that immature bone develops to support muscle mass accretion in the femur of broilers at different growth stage

Although maximum bone mineralization during growth increases dietary calcium requirements (Driver et al., 2005), mean calcium serum values remained constant, independently of treatment ( $p>0.05$; Table 3), in agreement with Barreiro et al. (2009). Since diet components influence mineral balance, affecting calcium blood levels (Schoulten et al., 2002), and because negative calcium balance modifies bone architecture (Siris et al., 2004), it is suggested that the experimental diets were nutritionally balanced, supporting calcium homeostasis of the birds.

Table 3 - Mean ( \pm standard deviation) calcium serum levels $(\mathrm{mg} / \mathrm{dL})$ of broilers supplied with filtered or unfiltered water between 14 and 45 days of age.

\begin{tabular}{lcc}
\hline Age (days) & Filtered water & Unfiltered water \\
\hline 14 & $794 \pm 1.96$ & $7.55 \pm 1.14$ \\
\hline 21 & $7.90 \pm 1.45$ & $8.05 \pm 1.12$ \\
\hline 45 & $8.93 \pm 2.03$ & $9.05 \pm 1.66$ \\
\hline Mean & $8.26 \pm 1.10$ & $8.22 \pm 0.89$ \\
\hline
\end{tabular}


The chemical analysis (Table 4) shows that two types of water used during the experiment were according to Conama Regulation 396, Brazil (2008).

The $\mathrm{pH}$ values were in the range recommended by the regulation legislation, between six and nine. The slightly alkaline $\mathrm{pH}$ is suitable for water consumption by birds. However, pH extremes may interfere with immunization and medication supplied via drinking water (Counotte, 2000).

Fluoride levels were below the maximum allowed levels, favoring bone physiology, because, according to Raffi et al. (1997), excessive amounts of fluoride can cause bone weakness in poultry. Similarly, manganese levels (Table 4) were below allowed limit for drinking water $(0.5 \mathrm{mg} / \mathrm{L})$ established by Palhares (2005). According to Faria et al. (2009), manganese activates several enzymes and is essential for the development of the bone organic matrix, reproduction, metabolism of carbohydrates and lipids, immune system, brain function and cell integrity. Manganese deficiency can cause nervous symptoms in young birds, perosis and chondrodystrophy.

The water supply of Faculdade de Ciências Agrárias e Veterinárias, UNESP, Jaboticabal, presented good chemical quality, with toxic and contaminant level below the maximum recommended levels or absent.

Table 4 - Chemical analysis of the filtered (T1) and unfiltered water (T2) used as drinking water for the broilers during a period of 45 days

\begin{tabular}{lccc}
\hline Parameters & T1 & T2 & Unit \\
\hline $\mathrm{pH}$ & 7.25 & 7.83 & Dimensionless \\
\hline Conductivity & 169.80 & 166.70 & $\mu \mathrm{cm}$ a $25^{\circ} \mathrm{C}$ \\
\hline Total hardness & 49.00 & 49.00 & $\mathrm{mg} / \mathrm{L} \mathrm{CaCO3}$ \\
\hline $\begin{array}{l}\text { Alkalinity of } \\
\text { hydroxides }\end{array}$ & 0.00 & 0.00 & $\mathrm{mg} / \mathrm{L} \mathrm{CaCO3}$ \\
\hline $\begin{array}{l}\text { Alkalinity of } \\
\text { carbonates }\end{array}$ & 0.00 & 0.00 & $\mathrm{mg} / \mathrm{L} \mathrm{CaCO3}$ \\
\hline Alkalinity of & 191.00 & 194.00 & $\mathrm{mg} / \mathrm{L} \mathrm{CaCO3}$ \\
bicarbonates & & & \\
\hline Sodium & 20.00 & 20.00 & $\mathrm{mg} / \mathrm{L} \mathrm{Na}$ \\
\hline Potassium & 3.00 & 2.10 & $\mathrm{mg} / \mathrm{L} \mathrm{K}$ \\
\hline Calcium & 18.20 & 18.10 & $\mathrm{mg} / \mathrm{L} \mathrm{Ca}$ \\
\hline Magnesium & 0.84 & 0.80 & $\mathrm{mg} / \mathrm{L} \mathrm{Mg}$ \\
\hline Copper & $<0.01$ & $<0.01$ & $\mathrm{mg} / \mathrm{L} \mathrm{Cu}$ \\
\hline Total iron & 0.01 & 0.01 & $\mathrm{mg} / \mathrm{L} \mathrm{Fe}$ \\
\hline Manganese & $<0.01$ & $<0.01$ & $\mathrm{mg} / \mathrm{L} \mathrm{Mn}$ \\
\hline Zinc & 0.01 & 0.01 & $\mathrm{mg} / \mathrm{L} \mathrm{Zn}$ \\
\hline Ammonium & 0.024 & 0.015 & $\mathrm{mg} / \mathrm{L} \mathrm{NH3}$ \\
\hline Nitrites & 0.006 & 0.008 & $\mathrm{mg} / \mathrm{L} \mathrm{NO}-$ \\
\hline Nitrates & $<0.001$ & 0.001 & $\mathrm{mg} / \mathrm{L} \mathrm{NO3-}$ \\
\hline Fluorides & 0.01 & $\mathrm{mg} / \mathrm{L} \mathrm{F-}$ \\
\hline Sulfates & & $\mathrm{mg} / \mathrm{L} \mathrm{SO3-}$ \\
\hline & & & \\
\hline
\end{tabular}

\section{CONCLUSIONS}

Bone mineral density values of broilers increase according to age. Good water quality affects organic calcium balance in broilers, favoring the maintenance of serum calcium levels between 14 and 45 of age and bone mineral density of the distal epiphysis of the tibia of 45 -d-old broilers.

\section{ACKNOWLEDGMENTS}

The authors thank Prof. Dr. Otto Mack Junqueira for providing the house poultry used for the experiment, and Prof. Dr. José Jurandir Fagliari and Renata Lemos Nagib Jorge, for the use of the biochemical analysis laboratory of Veterinary Hospital Laudo Natel. The encouragement and financial support of FAPESP (Fundação de Amparo à Pesquisa do Estado de São Paulo) is acknowledged, as well as the company Hidrofiltros $®$ for donating the water filter used during experiment.

\section{REFERENCES}

Almeida Paz ICL, Mendes AA, Takita TS, Vulcano LC, Guerra PC, Wescheler FS, Garcia, RG. Tibial Dyschondroplasia and bone mineral density. Brazilian Journal of Poultry Science 2004;6(4):207-212.

Almeida Paz ICL, Bruno LDG. Bone mineral density: review. Brazilian Journal of Poultry Science $2006 ; 8(2): 69-73$

Almeida Paz ICL. Problemas Locomotores e Técnicas de Mensuração. Simpósio sobre bem-estar de Frangos e Perús da Conferência APINCO de Ciência e Tecnologia Avícolas ; 2008; Santos, São Paulo. Brasil. p.5768.

Almeida Paz ICL, Mendes AA, Balog A, Vulcano LC, Vulcano LC, Ballarin AW, Almeida ICL, Takahashi SE, Komiyama CM, Silva MC, Cardoso KFG. Study on the bone mineral density of broiler suffering femoral joint degenerative lesions. Brazilian Journal of Poultry Science 2008; 10(2):103-108.

Almeida Paz ICL, Mendes AA, Martins MRFB, Fernandes BCS, Almeida $I C L$, Milbradt EL, Balog A, Komiyama CM. Femur mineral density of broilers with femoral degeneration fed high nutritional density diets. International Journal of Morphology 2009;27(2):595-599.

Angel R. Metabolic disorders: limitations to growth of and mineral deposition into the broiler skeleton after hatch and potential implications for leg problems. Journal of Applied Poultry Research 2007;16(1):138-149.

Araújo CSS, Artoni SMB, Araújo LF, Junqueira OM, Lousada MJQ, Oliveira D. Densidade óssea de frangos de corte alimentados com diferentes níveis de aminoácidos e cálcio durante a fase final de criação. Acta Scientiarum 2006;28(2):203-208

Barreiro FR, Sagula AL, Junqueira OM, Pereira GT, Baraldi-Artoni, SM Densitometric and biochemical values of broiler tibias at different ages. Poultry Science 2009;88(12):2644-2648.

Barreiro FR, Baraldi-Artoni, SM, Amaral LA, Barbosa JC, Girardi AM Pacheco MR, Amoroso L. Determination of broiler femur parameters at different growth phases. International Journal of Poultry Science 2011;10(11):849-853 
Brasil. Resolução CONAMA n 396, de 03 de abril de 2008. Dispõe sobre a classificação e diretrizes ambientais para o enquadramento das águas subterrâneas e dá outras providências. Diário Oficial da República Federativa do Brasil, Poder Executivo, Brasília, DF, 03 abr. 2008. Seção Resoluções, p. 71, 2008.

Bruno LDG, Macari M. Ingestão de água: mecanismos regulatórios. In: Macari M, Furlan RL, Gonzales E. Fisiologia aplicada a frangos de corte. Jaboticabal: Funep; 2002. p. 201-208.

Chang W, Tu C, Chen T, Bikle D, Shoback D. The extracellular calciumsensing receptor ( $\mathrm{CaSR}$ ) is a critical modulator of skeleton development. Science Sinaling 2008;1(35):1-13.

Clarke B. Normal bone anatomy and physiology. Clinical Journal of the American Society of Nephrology 2008;3(3):131-139.

Charuta A, Cooper RG. Computed tomographic and densitometric analysis of tibiotarsal bone mineral density and content in postnatal Peking ducks (Anas platyrhynchos var. domestica) as influenced by age and sex. Polish Journal of Veterinary Sciences 2012;15(3):537-545.

Counotte G. Understanding the quality of drinking water. World Poultry Science 2000;16(5):34-40.

Driver JP, Pesti GM, Bakalli RI, Edwards HM Calcium requirements of the modern broiler chicken as influenced by dietary protein and age. Poultry Science 2005;84:1629-1639.

Faria DE, Junqueira OM, Duarte KF. Doenças das aves. In: Berchieri Junior A, Silva EN, Di Fábio J, Sesti L, Zuanaze MAF. Enfermidades nutricionais. 2ed. Campinas: FACTA; 2009. p.927-971

Julian RJ. Production and growth related disorders and other metabolic diseases of poultry. A review. The Veterinary Journal 2005;169(3):350369.

Louzada MJQ, Pelá CA, Belangero WD, Santos-Pinto R. Densidade de peças ósseas de frangos. Estudo pela densitometria óptica radiográfica. Veterinária e Zootecnia 1997;9:87-94.

Mendonça Jr CX. Doenças das aves. In: Berchieri Junior A, Silva EN, Di Fábio J, Sesti L, Zuanaze MAF. Enfermidades Nutricionais. 2ed. Campinas: FACTA; 2009. p.175-187.

Oliveira MC, Silva D, Loch FC, Laurentiz AC, Junqueira OM. Effect of nonphytate phosphorus and phytase levels on broiler tibia. Archives of Veterinary Science 2009;14(1):49-56.

Palhares JCP. Qualidade de água para aves e suínos. Concórdia: Embrapa; 2005. p.1-2.

Raffi MB, Méndez MC, Riet-Correa F. Estudo histomorfométrico e histológico das lesões ósseas causadas por flúor em aves. Pesquisa Veterinária Brasileira 1997;17(2):69-76.

Rostagno HS. Tabelas brasileiras para aves e suínos - Composição de alimentos e exigências nutricionais. 2 ed. Viçosa: Universidade Federal de Viçosa; 2005

Saraiva GL, Lazaretti-Castro M. Marcadores Bioquímicos da Remodelação óssea na pratica clínica. Arquivo Brasileiro de Endocrinologia \& Metabologia 2002;46(1):72-78.

SAS Statistical analysis systems: system for microsoft windows, release 8.2 . Cary; 2004

Schoulten NA, Teixeira AS, Bertechini AG, Freitas RTF, Conte AJ, Silva OS. Efeito dos níveis de cálcio sobre a absorção de minerais em dietas iniciais para frangos de corte suplementadas com fitase. Ciências Agrotecnológicas 2002;26(6):1313-1321.
Scott ML, Nesheim MC, Young RJ. Essential inorganic elements: nutrition of the chicken. 3rd ed. New York (NY): M.L Scott Associates; 1982. p.287-304.

Siris ES, Chen YT, Abbott TA, Barrett-Connor E, Miller PD, Wehren LE, Berger ML. Bone mineral density thresholds for pharmacological intervention to prevent fractures. Archives of Internal Medicine. 2004;164(10):1108-111.

Yalçin S, Özkan S, Coskuner E, Bilgen G, Delen Y, Kurtulmus Y, Tanyalçin T. Effects of strain, maternal age and sex on morphological characteristics and composition of tibial bone in broilers. British Poultry Science 2001;42(2):184-190. 